\title{
The Impact of Cognitive-based Learning and Imagery Training on Tennis Skills
}

\author{
Mehmet Behzat Turan ${ }^{1, *}$, Osman Dişçeken ${ }^{2}$, Mustafa Kaya ${ }^{1}$ \\ ${ }^{1}$ Physical Education and Sport Department, Erciyes University, Kayseri, Turkey \\ ${ }^{2}$ Physical Education and Sport Department, HacıBektaşVeli University Nevşehir, Turkey
}

Copyright $@ 2019$ by authors, all rights reserved. Authors agree that this article remains permanently open access under the terms of the Creative Commons Attribution License 4.0 International License

\begin{abstract}
The aim of this study is to examine the impact of cognitive-based learning and imagery training on basic tennis skills to students who take elective tennis course.16 volunteers who take elective tennis course took part in the research. Control and experiment groups are formed by dividing volunteers into two equal groups. Control group $(n=8)$ and experiment group $(n=8)$ have only attended the tennis course and at the end of the first week "Hewitt" test is applied to both groups. After the test is applied both groups continued to attend tennis courses regularly for 8 weeks. Cognitive learning and imagery training is applied on the experimental group (PCG) in addition to their tennis lessons 2 periods of 30 minutes for 2 times per week, control group (PG), on the other hand, only continued the tennis training. At the end of $8^{\text {th }}$ week of tennis courses, "Hewitt" test is applied once more to the control and experiment group. Acquired data is statistically analysed with IBM SPSS 20 package program. In order to compare the acquired between groups, Independent ' $\mathrm{t}$ ' test, in groups Paired Sample $\mathrm{T}$ test is used. As a result analyzes, although there is no logical difference between control group and experiment group in pre-test scores, logical differences are determined in post-test scores $(\mathrm{p}<0.05)$. While no logical difference is determined in the pre-test and post-test comparison in control group, logical differences are determined in the pre-test and post-test comparison in experiment group ( $\mathrm{p}<0.05)$. As a result, it is found that cognitive-based learning and imagery training that applied to students has important impacts on basic tennis skills. According to these results, it is that cognitive-based learning and imagery training that applied to students thought to be positive in the development of basic tennis skills and may increase in athletic performance and sporting succession.
\end{abstract}

Keywords Cognitive-Based Learning, Imaginary Training, Tennis, Physical Education and Sport Teaching

\section{Introduction}

Cognitive learning is a complex, cognitive process beyond the relationship between stimuli and response. In the individual, behavior change occurs after some mental processes and learning takes place. Learning according to this approach is a result of an effort to understand what is actually happening around people and around the world. This can only be achieved by some activities that the individual has in his mind. Briefly, learning in the cognitive approach is an effective mental process a [1].

According to cognitive learning theory, knowledge can be easily structured and remembered as far as how much it is organized, interpreted as planned. While old cognitive approach emphasizes gaining information in learning, new approach mentions the configuration of information [2].

One of the most important approaches in cognitive approach, an individual obtains information and processes for oneself, in other words, shapes for oneself [3].

Information goes through four phases in process approach. These phases are the sensory record, short-term memory, long-term memory and control. With the help of sense organs, stimulants that come from environment transfer into short-term memory, working memory in other words, by sensory record. When in need, this information is summoned from long-term memory and it is processed in short-term memory [4].

Theories of cognitive learning often focus on internal processes and individual factors. It argues that learning is not related to the stimulus response, but that the stimuli that surround it are associated with similar experiences that exist in the brain and that new meanings are the result. Cognitive theorists have examined the internal processes between the acquisition of knowledge by sensory organs and the introduction of performance as a performance a [5].

According to Ryan and Simons (1981), imagery studies are more beneficial in sports which have cognitive processes to a large extent or require thinking a [6]. Cognitive theorists define learning as perceiving outer impulses, comparing the former information, generating 
new information memorizing and remembering the gathered information of individuals a [7] For example, imagery studies in tennis can be more beneficial than rope climbing or pull a [6]. Those who are closely acquainted with tennis state that a five-set tennis competition between equal strengths is stiffer and it tires body and minds more than a five thousand meter run, one and a half hour football match and many other sports branch [4]. Tennis, which forces a human's technical, tactical, physiological and psychological skills, is one of the best sports branches which develops physical, mental, sensual and social progress skills when it is done planned and programmed [8]. Tennis is actually a sport which requires more occupation, training and education than other sports branches.

For this reason, most of the trainers do not only use physical training in order to improve performance in such stiff and difficult branches, but they also include cognitive-based learning and mental training along with physical training in their exercises. With the help of researches, mental training is getting more and more important. Mental practice has been defined as, rehearsal of a physical task in the absence of observable movement, a passive learning process without physical activity and developing a known movement for a particular purpose without acting, only using the mind or preparatory trainings which learning new movements [9-10-11].

The most common area where imagery and mental training are used studying sports skills, skills can be got into a better form by imagining positively, skills' weaknesses can be put forth more successful and strong by fixing it. Studies show that successful athletes and trainers use mental training technic and strategies in order to achieve success [12]. Also, it is known that mental training and cognitive-based learning methods, which are learning accelerator methods, has enhancing effect on skill learning [13-14].

This study is done for the purpose of examining the impact of cognitive-based learning and imagery training on basic tennis skills through observed on university students who take the elective course and form the sample group.

\section{Material and Method}

\subsection{Study Design and Participants}

16 athletes who differ from 19-25 years old voluntarily have participated in the research. Subjects are; 8 people in the physical training group (PG), 8 people in the physical and cognitive training group (PCG). Groups are formed randomly. Subjects are informed about the purpose and the content of the study and their motivation levels are raised. Age, height, weight and body mass index (BMI) is used as descriptive parameters.

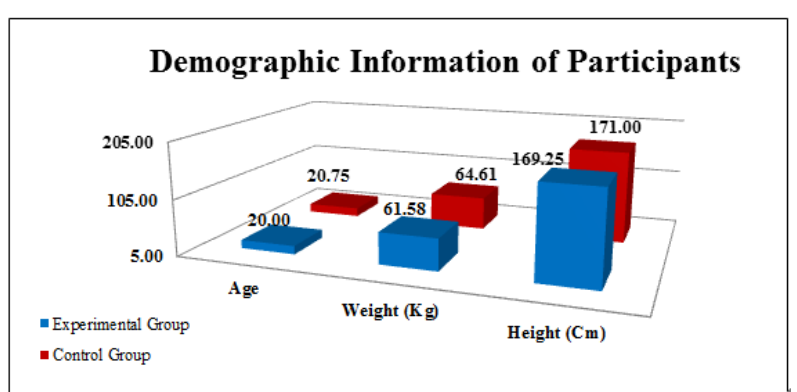

Training programs are applied to volunteers 2 times per week for 8 weeks. PG has only attended to tennis training physically. PCG, however, has attended cognitive training programs before every physical training. Hewitt test was applied to determine participants' forehand-backhand base technical hit hit ratios and impact strengths. Pre-test measurements are taken 3 days before training and at the end of the $8^{\text {th }}$ week, post-test measurements are taken.

\section{Procedure}

\subsection{Physical Training Protocol:}

Tennis training is applied to subjects 2 times per week for 8 weeks. Every training took 60 minutes and 10 minutes of warm-up before training and 10 minutes of cooling down after the training exercises are included at this time. For the remaining 40-minute training period, 25 minutes of developing stroke techniques (combined techniques such as steady, ground and above balls) and 15 minutes of basic tennis techniques (forehand and backhand) exercises took place in order to develop these techniques.

\subsection{Cognitive Training Protocol:}

Video supported cognitive training program in envisioning and accelerating the learning model [15-16] is applied to subjects 2 times per week for 8 weeks. Videos are taken from professional tennis players who perform the technique successfully and accurately. In order to enhance the subjects' visualisation skills, cognitive preparation techniques are applied before cognitive training for the first week [17]. and studies were made in order to envisage all the senses by doing warm-up exercises. Normal and slow-motion versions of successful athletes' videos who perform stroke techniques accurately are shown, emphasised on the important parts and explanations were made [16-18]. Basic performance practice and ideal model exercise [17] are applied and it is provided to visualise the techniques that subjects watched in videos. After visioning the technique in normal and slow-motion, the technique is visioned in lots of different perspectives such as first-person and third-person perspectives by using sense organs. In all of the visualisation sessions, successful strokes which hit the target is focused. Visualisation 
sessions which take 3-4 minutes [16] subjects are provided to take notes about the finished and watched techniques' perform. It is continued until the end of the process by adding more and more notes after every training. PCG has done the perform of the move after every cognitive training and consolidated by visualising again. After that, the technique that is performed is discussed with subjects by scrutinizing the taken notes [16].

Table 1. 8 weeks of cognitive-based, imagery and video supported basic tennis skills study program.

\begin{tabular}{|c|c|c|c|c|}
\hline \multirow{2}{*}{$\begin{array}{c}\text { Monday } \\
\text { First 30 } \\
\text { minutes }\end{array}$} & $\begin{array}{c}\text { Second 30 } \\
\text { minutes }\end{array}$ & $\begin{array}{c}\text { First 30 } \\
\text { minutes }\end{array}$ & $\begin{array}{c}\text { Second 30 } \\
\text { minutes }\end{array}$ \\
\cline { 2 - 5 } Week & $\begin{array}{c}\text { Training } \\
\text { plan }\end{array}$ & $\begin{array}{c}\text { Internal } \\
\text { training }\end{array}$ & $\begin{array}{c}\text { Technique } \\
\text { videos }\end{array}$ & $\begin{array}{c}\text { Internal } \\
\text { training }\end{array}$ \\
\hline $\begin{array}{c}\mathbf{2} \\
\text { Week }\end{array}$ & $\begin{array}{c}\text { Technique } \\
\text { videos }\end{array}$ & $\begin{array}{c}\text { Group } \\
\text { training }\end{array}$ & $\begin{array}{c}\text { Object } \\
\text { training }\end{array}$ & $\begin{array}{c}\text { Technique } \\
\text { videos }\end{array}$ \\
\hline $\begin{array}{c}\mathbf{3 .} \\
\text { Week }\end{array}$ & $\begin{array}{c}\text { Technique } \\
\text { videos }\end{array}$ & $\begin{array}{c}\text { Quiet } \\
\text { environment } \\
\text { training }\end{array}$ & $\begin{array}{c}\text { Internal } \\
\text { training }\end{array}$ & $\begin{array}{c}\text { Group } \\
\text { training }\end{array}$ \\
\hline $\begin{array}{c}\mathbf{4 .} \\
\text { Week }\end{array}$ & $\begin{array}{c}\text { Internal } \\
\text { training } \\
\text { environment } \\
\text { training }\end{array}$ & $\begin{array}{c}\text { Group } \\
\text { training }\end{array}$ & $\begin{array}{c}\text { Technique } \\
\text { videos }\end{array}$ \\
\hline $\begin{array}{c}\mathbf{5 .} \\
\text { Week }\end{array}$ & $\begin{array}{c}\text { Technique } \\
\text { videos }\end{array}$ & $\begin{array}{c}\text { Imagery } \\
\text { Technique } \\
\text { videos }\end{array}$ & $\begin{array}{c}\text { Cognitive } \\
\text { teaching }\end{array}$ \\
\hline $\begin{array}{c}\mathbf{6 .} \\
\text { Week }\end{array}$ & Imagery & $\begin{array}{c}\text { Technique } \\
\text { videos }\end{array}$ & $\begin{array}{c}\text { Cognitive } \\
\text { teaching }\end{array}$ & $\begin{array}{c}\text { Technique } \\
\text { videos }\end{array}$ \\
\hline $\begin{array}{c}\mathbf{7} . \\
\text { Week }\end{array}$ & $\begin{array}{c}\text { Noisy } \\
\text { environment } \\
\text { training }\end{array}$ & $\begin{array}{c}\text { Technique } \\
\text { videos }\end{array}$ & Imagery & $\begin{array}{c}\text { Technique } \\
\text { videos }\end{array}$ \\
\hline $\begin{array}{c}\mathbf{8 .} \\
\text { Week }\end{array}$ & $\begin{array}{c}\text { Technique } \\
\text { videos }\end{array}$ & $\begin{array}{c}\text { Quiet } \\
\text { environment } \\
\text { training }\end{array}$ & $\begin{array}{c}\text { Internal } \\
\text { training }\end{array}$ & $\begin{array}{c}\text { Technique } \\
\text { videos }\end{array}$ \\
\hline
\end{tabular}

As it can be seen in the table, in addition to internal, group, noisy environment, quiet environment, object, imagery (envisioning) and cognitive mental training [15] 8-week training programs are formed by showing more detailed technique videos in order to increase technical skill learning.

\section{Measurements}

\subsection{Height and Body Weight Measurement}

Body weight is measured with a weighbridge which has a $0,1 \mathrm{~kg}$ sensitivity and a metal stick in this weighbridge, height is measured with a digital height measuring device. Subjects are measured with only shorts and t-shirts. Measurements are taken in upright head, standing on weighbridge with straight soles, stretched knees, adjoining heels and upright body with barefoot [19-20].

\subsection{Body Mass Index}

It is obtained by comparing body weight with height's square in meter type formula [21].

\subsection{Hewitt Test}

In normal court are, court size is $23,77 \mathrm{~m}-10,97 \mathrm{~m}$, the height of the net $91 \mathrm{~cm}$ (net posts are not calculated) (Figure 1). The opposite side of the court is divided into 4 equal parts and has 4 different points. Between the net and the first gap (4.5m) is 1 point, between the first and the second gap $(4.5 \mathrm{~m})$ is 2 points, between the second and the third gap $(4.5 \mathrm{~m})$ is 3 points and between the third and the fourth gap $(4.5 \mathrm{~m})$ is 4 points (Figure 1). By feeding the athletes from the mini court line at the opposite side of them, coach throws 20 balls to the athletes and according to the gap the ball first drops by returning it with forehand and backhand, the total score of the athlete is written down as the stroke performance. Hitting the ball in the net or dropping the ball outside of the court lines are counted as fail hits and given zero points [22].

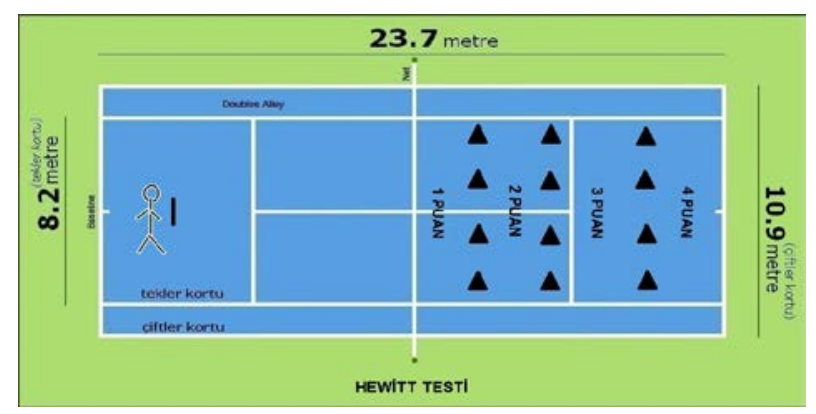

Figure 1. Hewitt Test

\section{Statistical Analysis}

Obtained data from the study are evaluated in SPSS 20 program. At first descriptive statistics were made. After that, since study group is less than 50 subjects, whether the data show normal distribution or not, it is determined by Shapiro-Wilk test, skewness and kurtosis with histogram, examining the Q-Q, P-P graphics. Since data show normal distribution, Paired Samples $\mathrm{T}$ test in intra-group, Independent Samples $\mathrm{T}$ test is used in inter-group measurements. Level of significance is accepted as $\mathrm{p}<0,05$.

\section{Findings}

When Table 2 is examined, control group is formed with 5 male 3 female students whose average age is $20 \mathrm{i} 75 \pm 1.28$, average weight is $64.61 \pm 9.65$, average height is $171.00 \pm 6.35$ and experiment group is formed with 5 male 3 female students whose average age is $20.00 \pm .75$, average weight is $61.58 \pm 8.79$, average height is $169.25 \pm 4.46$.

When Table 3 is examined no logical difference can be seen between experiment and control groups' Forehand Parallel, Forehand Cross, Backhand Parallel, Backhand Cross, Total Forehand and Backhand Parallel, Total Forehand And Backhand Cross pretest scores $(\mathrm{p}<0,05)$. 
Table 2. Applicants Descriptive Statistics

\begin{tabular}{|c|c|c|c|c|c|}
\hline Group & $\begin{array}{c}\text { Variable } \\
\mathrm{s}\end{array}$ & $\mathbf{N}$ & $\begin{array}{c}\text { Minimu } \\
\text { m }\end{array}$ & $\begin{array}{c}\text { Maximu } \\
\text { m }\end{array}$ & $\bar{x} \pm S D$ \\
\hline \multirow{3}{*}{$\begin{array}{l}\text { Control } \\
\text { Group }\end{array}$} & Age & 8 & 19.00 & 23.00 & $20.75 \pm 1.28$ \\
\hline & $\begin{array}{l}\text { Weight } \\
\text { (Kg) }\end{array}$ & 8 & 51.56 & 75.60 & $64.61 \pm 9.65$ \\
\hline & $\begin{array}{l}\text { Height } \\
(\mathrm{Cm})\end{array}$ & 8 & 162.00 & 181.00 & $\begin{array}{c}171.00 \pm 6.3 \\
5 \\
\end{array}$ \\
\hline \multirow{3}{*}{$\begin{array}{c}\text { Experimen } \\
\text { t Group }\end{array}$} & Age & 8 & 19.00 & 21.00 & $20.00 \pm .75$ \\
\hline & $\begin{array}{l}\text { Weight } \\
\text { (Kg) }\end{array}$ & 8 & 52.80 & 74.72 & $61.58 \pm 8.79$ \\
\hline & $\begin{array}{l}\text { Height } \\
(\mathrm{Cm})\end{array}$ & 8 & 162.00 & 175.00 & $\begin{array}{c}169.25 \pm 4.4 \\
6\end{array}$ \\
\hline
\end{tabular}

Table 3. Comparison of Control and Experiment Group Pre Test

\begin{tabular}{|c|c|c|c|c|c|}
\hline & Group & $\mathrm{N}$ & $\overline{\mathrm{x}} \pm \mathrm{SD}$ & $\mathrm{t}$ & $\mathrm{p}$ \\
\hline \multirow{2}{*}{$\begin{array}{c}\text { Forehand } \\
\text { Parallel }\end{array}$} & Control & 8 & $9.13 \pm 5.33$ & \multirow{2}{*}{.260} & \multirow{2}{*}{.798} \\
\hline & Experiment & 8 & $8.50 \pm 4.21$ & & \\
\hline \multirow{2}{*}{$\begin{array}{c}\text { Forehand } \\
\text { Cross }\end{array}$} & Control & 8 & $10.50 \pm 4.96$ & \multirow{2}{*}{.682} & \multirow{2}{*}{.507} \\
\hline & Experiment & 8 & $8.63 \pm 5.99$ & & \\
\hline \multirow{2}{*}{$\begin{array}{c}\text { Backhand } \\
\text { Parallel }\end{array}$} & Control & 8 & $9.25 \pm 6.88$ & \multirow{2}{*}{1.155} & \multirow{2}{*}{.267} \\
\hline & Experiment & 8 & $6.00 \pm 4.00$ & & \\
\hline \multirow{2}{*}{$\begin{array}{l}\text { Backhand } \\
\text { Cross }\end{array}$} & Control & 8 & $6.63 \pm 3.54$ & \multirow{2}{*}{-.876} & \multirow{2}{*}{.396} \\
\hline & Experiment & 8 & $8.63 \pm 5.40$ & & \\
\hline \multirow{2}{*}{$\begin{array}{c}\text { Total } \\
\text { Parallel }\end{array}$} & Control & 8 & $18.38 \pm 9.59$ & \multirow{2}{*}{.913} & \multirow{2}{*}{.376} \\
\hline & Experiment & 8 & $14.50 \pm 7.21$ & & \\
\hline \multirow{2}{*}{ Total Cros } & Control & 8 & $17.13 \pm 7.10$ & \multirow{2}{*}{-.030} & \multirow{2}{*}{.977} \\
\hline & Experiment & 8 & $17.26 \pm 9.49$ & & \\
\hline
\end{tabular}

When Table 4 is examined a logical difference can be seen between experiment and control groups' Forehand Parallel, Forehand Cross, Backhand Parallel, Backhand Cross, Total Forehand-Backhand Parallel, Total Forehand-Backhand Cross pretest scores $(\mathrm{p}<0,05)^{* *}$.

Table 4. Comparison of Control and Experiment Group Posttest

\begin{tabular}{|c|c|c|c|c|c|}
\hline & Group & $\mathrm{N}$ & $\overline{\mathrm{x}} \pm \mathrm{SD}$ & $\mathrm{t}$ & $\mathrm{p}$ \\
\hline \multirow{2}{*}{$\begin{array}{c}\text { Forehand } \\
\text { Parallel }\end{array}$} & Control & 8 & $11.88 \pm 3.68$ & \multirow{2}{*}{-5.132} & \multirow{2}{*}{$.000 * *$} \\
\hline & Experiment & 8 & $19.13 \pm 1.55$ & & \\
\hline \multirow{2}{*}{$\begin{array}{c}\text { Forehand } \\
\text { Cross }\end{array}$} & Control & 8 & $13.13 \pm 3.87$ & \multirow{2}{*}{-2.535} & \multirow{2}{*}{$.024 *$} \\
\hline & Experiment & 8 & $23.13 \pm 10.47$ & & \\
\hline \multirow{2}{*}{$\begin{array}{c}\text { Backhand } \\
\text { Parallel }\end{array}$} & Control & 8 & $12.63 \pm 2.88$ & \multirow{2}{*}{-4.637} & \multirow{2}{*}{$.000 * *$} \\
\hline & Experiment & 8 & $18.63 \pm 2.27$ & & \\
\hline \multirow{2}{*}{$\begin{array}{c}\text { Backhand } \\
\text { Cross }\end{array}$} & Control & 8 & $10.00 \pm 4.21$ & \multirow{2}{*}{-3.421} & \multirow{2}{*}{$.004 * *$} \\
\hline & Experiment & 8 & $17.13 \pm 4.12$ & & \\
\hline \multirow{2}{*}{$\begin{array}{c}\text { Total } \\
\text { Parallel }\end{array}$} & Control & 8 & $24.50 \pm 5.42$ & \multirow{2}{*}{-6.303} & \multirow{2}{*}{$.000 * *$} \\
\hline & Experiment & 8 & $37.75 \pm 2.43$ & & \\
\hline \multirow{2}{*}{$\begin{array}{l}\text { Total } \\
\text { Cross }\end{array}$} & Control & 8 & $23.12 \pm 7.32$ & \multirow{2}{*}{-3.943} & \multirow{2}{*}{$.001 * *$} \\
\hline & Experiment & 8 & $40,25 \pm 9,87$ & & \\
\hline
\end{tabular}

When Table 5 is examined no logical difference can be seen when pretest and post-tests of experiment and control groups' Forehand Parallel, Forehand Cross, Backhand Parallel, Backhand Cross, Total Forehand-Backhand Parallel, Total Forehand-Backhand Cross scores are compared $(\mathrm{p}<0,05)$.

Table 5. Comparison of Control Group's Pre Test and Posttest

\begin{tabular}{|c|c|c|c|c|c|}
\hline & Group & $\mathrm{N}$ & $\overline{\mathrm{x}} \pm \mathrm{SD}$ & $\mathrm{t}$ & $\mathrm{p}$ \\
\hline \multirow{2}{*}{$\begin{array}{c}\text { Forehand } \\
\text { Parallel }\end{array}$} & Pre Test & 8 & $9.13 \pm 5.33$ & \multirow{2}{*}{-1.240} & \multirow{2}{*}{.255} \\
\hline & Posttest & 8 & $11.88 \pm 3.68$ & & \\
\hline \multirow{2}{*}{$\begin{array}{c}\text { Forehand } \\
\text { Cross }\end{array}$} & Pre Test & 8 & $10.50 \pm 4.96$ & \multirow{2}{*}{-1.350} & \multirow{2}{*}{.219} \\
\hline & Posttest & 8 & 13.13 & & \\
\hline \multirow{2}{*}{$\begin{array}{c}\text { Backhand } \\
\text { Parallel }\end{array}$} & Pre Test & 8 & $9.25=$ & \multirow{2}{*}{-1.510} & \multirow{2}{*}{.175} \\
\hline & Posttest & 8 & $12.63 \pm 2.88$ & & \\
\hline \multirow{2}{*}{$\begin{array}{l}\text { Backhand } \\
\text { Cross }\end{array}$} & Pre Test & 8 & $6.63 \pm 3.54$ & \multirow{2}{*}{-1.743} & \multirow{2}{*}{.125} \\
\hline & Posttest & 8 & $10.00 \pm 4.21$ & & \\
\hline \multirow{2}{*}{$\begin{array}{c}\text { Total } \\
\text { Parallel }\end{array}$} & Pre Test & 8 & $18.38 \pm$ & \multirow{2}{*}{-2.178} & \multirow{2}{*}{.066} \\
\hline & Posttest & 8 & $24.50 \pm 5.42$ & & \\
\hline \multirow{2}{*}{ Total Cross } & Pre Test & 8 & $17.13 \pm 7.10$ & \multirow{2}{*}{-1.891} & \multirow{2}{*}{.101} \\
\hline & Posttest & 8 & $23.13 \pm 7.32$ & & \\
\hline
\end{tabular}

When Table 6 is examined a logical difference can be seen when pretest and post-tests of experiment and control groups' Forehand Parallel, Forehand Cross, Backhand Parallel, Backhand Cross, Total Forehand-Backhand Parallel, Total Forehand-Backhand Cross scores are compared $(\mathrm{p}<0.05)$.

Table 6. Comparison of Experiment Group’s Pre Test and Posttest

\begin{tabular}{cccccc}
\hline & Group & $\mathrm{N}$ & $\overline{\mathrm{x}} \pm \mathrm{SD}$ & $\mathrm{t}$ & $\mathrm{p}$ \\
\hline $\begin{array}{c}\text { Forehand } \\
\text { Parallel }\end{array}$ & Pre Test & 8 & $8.50 \pm 4.21$ & -5.928 & $.001^{* *}$ \\
\hline $\begin{array}{c}\text { Forehand } \\
\text { Cross }\end{array}$ & Posttest & 8 & $19.13 \pm 1.56$ & & \\
\hline $\begin{array}{c}\text { Backhand } \\
\text { Parallel }\end{array}$ & Posttest & 8 & $23.13 \pm 10.47$ & -2.904 & $.023^{*}$ \\
\hline $\begin{array}{c}\text { Backhand } \\
\text { Cross }\end{array}$ & Prest & 8 & $6.00 \pm 4.00$ & -8.227 & $.000^{* *}$ \\
\hline $\begin{array}{c}\text { Total } \\
\text { Parallel }\end{array}$ & 8 & $18.63 \pm 2.27$ & & \\
\hline Post & Pre Test & 8 & $8.63 \pm 5.39$ & -3.685 & $.008^{*}$ \\
Cross & Posttest & 8 & $37.76 \pm 2.43$ & -8.188 & $.000^{* *}$ \\
\hline & Pre Test & 8 & $17.26 \pm 9.49$ & -3.922 & $.006^{*}$ \\
\hline
\end{tabular}

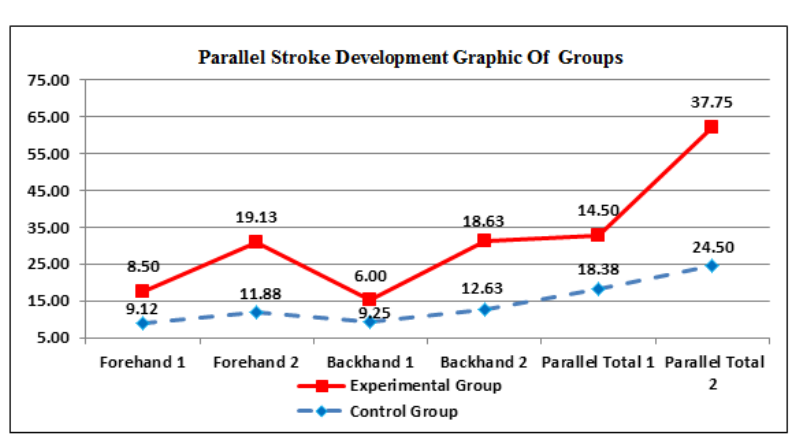

Graphic 1.Parallel Stroke Development Graphic of Groups 


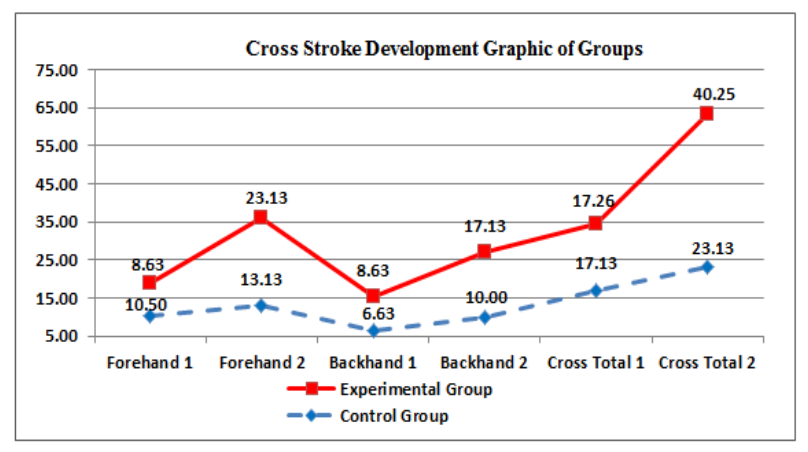

Graphic 2.Cross Stroke Development Graphic of Groups

\section{Discussion and Result}

Everyone that engages in sports activities faces both physical and mental loads. In order to minimize the effect of these loads, there is training being conducted against the factors that cause the load. But in training, what is mostly focused on is usually fitness exercises, technical and tactical training [23]. Mental training is one of the concepts that an athlete must learn and apply in the training program in addition to the annual training training [24].

Cognitive learning supports the imagination in this sense. The process of receiving, understanding, and analyzing information begins to be revived in the mind and this is reflected outside with time. In fact, what is defined as the change in behavior in cognitive learning is exactly the reflection of the learning process that takes place in the mind.

We started this study to investigate the effect of cognitive-based learning and imaginary training on basic tennis skills in our research. When we looked at the initial values in our study, there was no significant difference between experiment (PCG) and control (PG) groups pretest Forehand Parallel, Forehand Cross, Backhand Parallel, Backhand Cross, Forehand and Backhand Parallel Total and Backhand Cross total scores $(\mathrm{p}<0,05)$. This shows that the study group is homogeneously distributed.

When we look at the final test, significant differences were found between the experiment and control groups' Forehand Parallel, Forehand Cross, Backhand Parallel, Backhand Cross, Forehand-Backhand Parallel Total, Forehand and Backhand Cross total scores $(\mathrm{p}<0,05)$.

This shows that cognitive-based learning and imagery exercises applied for 8 weeks have positive effects on learning skills. The most common use of mental training is the study of sports skills. Skills can be made good with positive imagination, they can be manifested more successfully and powerfully by correcting their weak sides. Mental training is a psychological skill and it has an important power to improve the athlete's performance [15-25].

When we look at the statistical examination made between the groups; no significant difference between Forehand Parallel, Forehand Cross, Backhand Parallel, Backhand Cross, Forehand and Backhand Parallel Total, Forehand and Backhand Cross Total scores of Control (PG) group pretest and posttest was found. However, a significant difference was found between Forehand Parallel, Forehand Cross, Backhand Parallel, Backhand Cross, Forehand and Backhand Parallel Total, Forehand and Backhand Cross Total scores of the experimental group (PCG) pre-test and post-test.

After the studies he made, Gültekin (2006) stated that athletes think that if they use spiritual power same problems would not repeat in their own lives [26]. Individuals who think positive have higher chance to have positive results throughout their lives.

Botwina and Krawczynski (2003) has examined the impact of mental training on penalty kick in their studies and confirmed that both mental and physical training group has more accurate kicks compared to other two groups [27].

In Van Gyn and his friends' (1990) study, they have examined the impact of imagery on performance and they found a logical difference in both imagery and strength training in the acquired data, on the other hand, they couldn't find any logic in imagery training group only [28]. Mental training and imagery studies are very effective techniques but they are no substitute for physical training. For this reason, these techniques should be planned, compounded and should be used with physical training [17-29]. Trainers can obtain decision making with elite athletes and more effective imagery searching by giving more practice time to distinct learning approaches during comprehensive perceptual motor training program [30]. When mental training is combined with a distinct physical training, it can be stated that it has more positive results than not combining at all [25]. The findings we have acquired in our study support the literature.

Being an elite athlete brings a lot of discipline with it. It is thought that in this process with the help of thinking power and imagery training, athletes' physical performance will be increased along with his/her quality of life [31].

As a result, cognitive-based learning and imagery training has an impact on stroke skills in tennis. Besides physical training, mental training is also effective in learning motor skills. Furthermore, it can be stated that physical training with mental training study is more effective than single-handed physical or mental training and it is suggested that while preparing annual training program, mental training should be run together with physical training sessions.

Suggestions: With the help of cognitive-based learning methods we can provide an advantage on both the duration of skill learning and the perfection of the technique compared to the normal process of teaching the skill and technical sufficiency. 


\section{Suggestions}

1. In sports branch, cognitive education and imagery training should take place in basic skill education.

2. Possibilities should be presented to athletes/students which support the cognitive learning process such as video, analysis.

3. In skill learning, cognitive education process and imagery training processes should be introduced to students/athletes as a priority.

\section{Declaration of Conflicting Interests}

The author(s) declared no potential conflicts of interest with respect to the research, authorship, and/or publication of this article.

\section{Funding}

The author(s) received no financial support for the research, authorship, and/or publication of this article.

\section{REFERENCES}

[1] (http://notoku.com/bilissel-ogrenme-yaklasimi/\#ixzz5FKK uthcQ) (14.05.2018)

[2] Duman, B. (2004). Ögrenme Ögretme Kuramları ve Süreç Temelli Ögretim, Ankara: Anı Yayıncılık 68-72.

[3] Yüksel.Ö. (2004). Eğitimde Yeni Değerler, 9. Bask1. Pegem Yayınc1lık, Ankara 22-63..

[4] Ataman, A. (2004). Gelişim ve Öğrenme, Gündüz Eğitim ve Yayıncilık Ankara: (2), 278-322.

[5] (http://www.kpsskonu.com/egitim-bilimleri/ogrenme-psik olojisi/ogrenme-kuramlari/) (14.05.2018)

[6] Ryan, ED., Simons, J. (1981). “Cognitive demand imagery and frequency of mental practice as factors influencing the acquisition of mental skills”, Journal of Sport Psychology, 15:1-15.

[7] Erden, M. (1998). SosyalBilgilerÖgretimi, Ankara: AlkımYayınları.

[8] Haşı1, N., Ataç, H. (1988). Tenis Alıștırma Örnekleri, Bursa, Akmat Akınoğlu Matbaacılık, 1998; 1.

[9] Hecker, JE. Kaczor, LM., (1988). Application of Imagery Theory to Sport Psychology. J. Sport and Exercise Psychology, 10:363-373.

[10] Singer, RN. (1980). Motor Learning and Human Performance, 3rd Ed. Macmilian, New York, 251-267.

[11] Konter, E. (1999). Uygulamalı Spor Psikolojisinde Zihinsel Antrenman. Nobel Yayın Dağıtım, Ankara, 6-56.

[12] Durand, B.N., Salmela, JH. (1993). the Development and Maintenance of Expert Athletic Performance: Perceptions of World and Olympic Champions. Journal of Applied
Sport Psychology, 2002, 14:154-171. Exercise and Sport, 64:453-468.

[13] May, JR. (1986). Sport Psychology: Should Psychologists Become Involved? The Clinical Psychologist, 39(3):77-81.

[14] [Mahoney, M., Suinn, RM., (1986). History and Overview of Modern Sport Psychology, the Clinical Psychologist, 39(3):64-68.

[15] Aktepe 2006).K. Sporda Zihinsel Antrenmanın Önemi Ve Ferdi Milli Sporcuların Zihinsel Antrenman Ilgi Ve Uygulama Düzeylerinin Tespiti. Niğde Üniversitesi Sosyal Bilimler Enstitüsü. Yükseklisanstezi, 11-15.

[16] Kolayiş, H. (2002). Futbolcularda Zihinsel Hayal Etme Antrenmanının Kaygı Üzerine Etkisi. Yüksek Lisans Tezi, Kocaeli Üniversitesi, Sağlık Bilimleri Enstitüsü, Kocaeli, 28-42.

[17] Syer, J. Connolly, C. (1998). SporcularİçinZihinselAntren manRehberi, BağırganYayımevi, Ankara 47-56.

[18] Başer E. (1998). Uygulamalı Spor Psikolojisi, 3 Bas. Bağırgan Yayımevi, Ankara: 186-226.

[19] Tamer, K. (1995).SpordaFizikselFizyolojikPerformansınÖl çülmesiveDeğerlendirilmesi, Türkerler Kitabevi, Ankara.

[20] Verducci, F. (1980). Measurement Concepts in Physical Education, 1st Ed. The C.V. Mosby Company, London.

[21] Ergün, A., Ertan, SF. (2004). ÖğrencilerdeVücutKitleİndeksiVeBelÇevresiDeğerlerinin $\dot{I}$ ncelenmesi, Ankara Üniversitesi Tıp Fakültesi, 57(2):57-61.

[22] Kamar, A. (2008). Sporda Yetenek ve Performans Testleri. Nobel Yayın Evi, 2.Bask1, Ankara, 120-130.

[23] İkizler, C. (1997). Sporda Başarının Psikolojisi, 3.Baskı Alfa Basım Yayım Dağıtım, 35-64.

[24] Karagözoğlu, C. (2005). Sporda Psikolojik Destek, Morpa Kültür Yayınları, İstanbul, 56-87.

[25] Altıntaş, A., Akalan, C. (2008). Zihinsel Antrenman ve Yüksek Performans, Spormetre; 6(1), 39-43.

[26] Gültekin, A. (2006). Psikolojik Danışmanlık ve Rehberlik Öğrencilerinin Problem Çözme Becerilerinin İncelenmesi, A.Ü. Sosyal Bilimleri Enstitüsü, Yüksek Lisans Tezi, Erzurum, 10-12.

[27] Botwina, R. Krawczynski, M. (2003). Appilication of Visulation in Training of Young Football Players, 11. EuropeanCongress of Sport Psychology, 145.

[28] Van Gyn, Gh. Wenger, Ha. Gaul, Ca. (1990). Imagery as a Method of Enhancing Transfer from Training toPerformance, Journal of Sportand Exercise Psychology, 12: 366-375.

[29] Konter, E. (1998). Psikolojik Hazırlığın Teorive Pratiği, Bağırgan Yayımevi, Ankara, 32-61.

[30] Milazzo, N. Farrow.,D.,Fournier, JF. (2016). Effect of Implicit Perceptual-Motor Training On Decision-Making Skills and Underpinning Gaze Behavior in Combat Athletes. Perceptual and Motor Skills, 123(1),1.

[31] Biçer, T. (1998). Doruk Performans. 2. Bask1, Beyaz Yayınları, İstanbul, 168-170 